\title{
The Importance of Store Image and Retail Service Quality in Private Brand Image-Building
}

\author{
Adi Alić, Emir Agić, Merima Činjarević
}

\begin{abstract}
A B S T R A C T
Objective: The purpose of this research is to highlight the role which store image and retail service quality can play in private brand image-building in the context of an emerging market in South-Eastern Europe (i.e. Bosnia and Herzegovina). We propose to address this issue by seeking answers to the following questions: (1) Does a 'halo effect' take place between the store image and the private brand image? (2) How does consumer's evaluation of the quality of the service delivered by a retailer affect the image of its private brand?

Research Design \& Methods: Data were collected through a field survey via the storeintercept method. The sample consisted of 699 customers of two large retail chains. The data were analysed using the Structural Equation Modelling technique.

Findings: The findings of the present study suggest that store image and retail service quality are important factors in the formation of the image of product-branded products.

Implications \& Recommendations: This study offers some important insights for retailers who intend to develop their private brand. First, the image transfer from store brand to private brand suggests that retailers should consider the introduction of a private brand as a brand extension, with their stores as the parent brand. Second, we recommend that retailers put more emphasis on quality improvement initiatives related to the store environment attributes.

Contribution \& Value Added: This study enhances the discussion on the phenomenon of private branding by analysing the store-level factors which underpin the formation of private brand image in the context of less developed European markets.

$\begin{array}{ll}\text { Article type: } & \text { research paper } \\ \text { Keywords: } & \text { retailing; private brands; store image; service quality } \\ \text { JEL codes: } & \text { M30 }\end{array}$

Received: 25 March 2016 Revised: 31 August 2016 Accepted: 21 November 2016
\end{abstract}

Suggested citation:

Alić, A., Agić, E., \& Činjarević, M. (2017). The Importance of Store Image and Retail Service Quality in Private Brand Image-Building. Entrepreneurial Business and Economics Review, 5(1), 27-42, DOI: http://dx.doi.org/10.15678/EBER.2017.050102 


\section{INTRODUCTION}

Private brands (here PBs), also known as private labels, own brands, retailer brands, house brands, store brands or distributor brands, are brands owned and sold by a retailer in its own stores (Diallo, 2012). These brands have undergone a profound transformation over the years - from generics to copycats or mimics to premium brands (Kumar \&Steenkamp 2007). Initially positioned as cheap, low-quality unbranded alternatives to national brands, nowadays PBs are viewed as trusted brands with equity (Cuneo, Lopez \&Yague, 2012) which can compete head-to-head with national brands (Huang \& Huddleston, 2009). The birth, the evolution and the rise of PBs have had a tremendous impact on the retail landscape. This became increasingly apparent in recent years when almost all major retailers have launched PB programs across many product categories (Collins-Dodd \& Lindley, 2003; Vahie \&Paswan, 2006). According to the Private Label Manufacturer's Association (PLMA), one-third of basic grocery and household items in American supermarkets, drug chains, and mass merchandisers are sold under a PB. In Western Europe, PB penetration exceeds $50 \%$ sales by volume in Spain and Switzerland and more than $40 \%$ in major markets, such as the United Kingdom, Germany, Portugal, Belgium, and Austria (PLMA, 2015). Given this impressive growth and penetration of PBs in many North American and Western European retail markets, it is not surprising that the topic of private branding has attracted considerable interest among marketing scholars and practitioners.

Although a lot of research has been undertaken within a broad field of branding, scholars nevertheless argue that additional academic efforts are required in the area of private branding (Ailawadi \& Keller, 2004; Beneke, Brito \& Garvey, 2015; Calvo-Porral Martinez-Fernández, Juanatey-Boga, \& Lévy-Mangin, 2013; Diallo, 2012). According to Ailawadi \& Keller (2004), understanding how retailers create their brand images and how these images influence consumer perceptions of PBs should be considered as a research prirority in the area of private branding. Given that PBs are more multi-sensory in nature than product brands, and can rely on rich consumer experience to impact their equity, retailers can create their images in different ways, e.g. by attaching unique associations to the quality of their service, their in-store atmosphere, their product assortment or their pricing policy (Ailawadi \& Keller, 2004). Nevertheless, there is a lack of research addressing the issue of the formation of PB image from the consumer's standpoint (Vahie \& Paswan, 2006; Wu, Yeh \& Hsiao, 2011).

Therefore, this paper strives to enhance our understanding of the phenomenon of private branding by analysing the store-level factors (store image and retail service quality) which underpin the formation of PB image among consumers in Bosnia and Herzegovina. Drawing on the cue utilisation theory (Olson \& Jacoby, 1972) and stimulusorganism-response (S-O-R paradigm (Mehrabian \& Russell, 1974), we propose a conceptual model of the PB image formation. This study employs the quantitative survey-based approach to test the hypotheses based on the proposed conceptual framework which delineates the relationship between store image, retail service quality and PB image. The data were analysed using the Structural Equation Modelling (SEM) technique.

The next section provides the theoretical background and the development of hypotheses. The following section outlines the study's methodology with a focus on data collection and measurement issues. The fourth section presents and discusses the find- 
ings of the empirical study which was undertaken by using structural equation modelling to test the research hypotheses. Finally, theoretical and managerial implications, limitations and research orientations for future studies are presented.

\section{LITERATURE REVIEW}

This section provides a brief overview of concepts underpinning the proposed model which relates the dimensions of PB image, as dependent variable, to store image and service quality dimensions, as explicative variables. The cue utilization theory (Olson \& Jacoby, 1972) and stimulus-organism-response (S-O-R) paradigm (Mehrabian \& Russell, 1974) were applied to develop theoretical arguments underlying research hypotheses. The cue utilization theory states that consumers rely on both extrinsic and intrinsic cues to make judgments about product's overall excellence or quality (Olson \&Jacoby, 1972), whereas the S-O-R paradigm posits that stimuli from environments affect an individual's cognitive and affective reactions, which in turn lead to some behaviour (Mehrabian \& Russell, 1974). Both theories have been widely applied to study consumer behaviour related to PBs (e.g. Bao, Bao \& Sheng, 2011; Calvo-Porral et al., 2013; Collins-Dodd \& Lindley, 2003; Huang, 2009; Wu et al., 2011).

\section{Private Brand (PB) Image}

Before attempting to define PB image it necessary to understand the concept of brand image. Brand management scholars (Aaker, 1991; Keller, 1993) have argued that brand image is an essential part of powerful brands, which enables businesses to differentiate themselves from competitors. Although brand image is a relevant concept in consumer behaviour, there is still no agreement about its definition and measurement. According to Keller (1993), brand image is made up of brand association and it is defined as "the perceptions about a brand as reflected by the brand associations held in consumer memory" (Keller, 1993, p. 3). A similar definition was provided by Aaker (1991) who defines brand image as "a set of associations, usually organized in some meaningful way" (Aaker, 1991, p. 109). According to Keller (1993), these associations can be classified into three major categories: (1) attributes, i.e. descriptive features of the product itself and attributes linked to the purchase and/or consumption, (2) benefits, i.e. personal value which consumers attach to the brand attributes, and ( 3 ) attitudes, i.e. consumer's overall evaluation of a brand. Brand image is, therefore, a mental picture of a brand or a branded product/service and includes symbolic meanings which consumers associate with the specific attribute of a product/service (Dobni \& Zinkhan, 1990). Despite the proliferation of the ways in which brand image has been conceptualised and operationalised, there is widespread agreement among scholars that overall brand image encompasses functional or cognitive and affective components (Martínez Salinas \& Pina Pérez, 2009; Low \& Lamb, 2000).

The above mentioned discussion on brand image can be applied equally well to private branding. PB image refers to tangible or cognitive aspects, such as quality, price, or attributes related to the PB, as well as to intangible or affective aspects of the PB which consumers can form directly through their own experience or indirectly by advertising or some other sources of information (Keller, 2008). Thereby, PB image is a multidimensional concept which includes two components: quality image and affective image (Vahie \& Paswan, 2006; Wu et al., 2011). Previous studies suggest that product brand image is determined by 
numerous factors, such as product attributes, the marketing mix, the individual perceptions of the brand, personal values, experience, the type of brand users and context variables (Dobni \& Zinkhan, 1990). However, the private branding literature suggests that store image and perceived service quality are two prominent antecedents of PB image (Bao et al., 2011; Beneke \& Zimmerman, 2014; Wu et al., 2011). Due to their noteworthy acclaim, this study sheds some light on their significance in the formation of PB image.

\section{Store Image and Private Brand (PB) Image}

Despite the wealth of literature (theoretical, empirical and descriptive), it is still not quite clear what constitutes a store image or how retailers should go about building it (Theodoridis \& Chatzipanagiotou, 2009). One of the first definitions of the concept of a store image was offered by Martineau (1958). He describes store image as the "way in which the store is defined in the shopper's mind, partly by its functional qualities and partly by an aura of psychological attributes" (Martineau, 1958. p. 47). Thus, store image is determined by a complex combination of both tangible (functional) and intangible (psychological) attributes which consumers attach to a particular store (Beneke, Brito \& Garvey, 2015). In order to identify and classify attributes which together form the overall store image, a number of previous studies have used a multi-attribute approach (e.g. Bloemer \& de Ruyter, 1998; Diallo, 2012; Liljander, Polsa \& van Riel, 2009; Vahie \& Paswan, 2006). For instance, Bloemer and de Ruyter (1998) provide a list of attributes which influence the overall store image, including location, merchandise, store atmosphere, customer service, price, advertising, personal selling and sales incentive programmes. According to Chowdhury, Reardon and Srivastava (1998), the key elements or attributes determining a store image are: product selection, product quality, employee service, atmosphere, convenience, and price/value. Beneke et al. (2015) observed that the most commonly studied store image attributes are product quality, store quality, store atmosphere, layout, service, convenience, price level and assortment. For the purpose of this study, store image is defined as a set of commercial brand affiliations which pertain to the store in the consumer's mind (Beristain \& Zorrilla, 2011). In accordance with previous studies (Collins-Dodd \& Lindley, 2003; Wu et al., 2011), we placed focus on the following store image attributes: product variety, employee service, store atmosphere, price, product quality and the overall attitude.

Many researchers have sought to better understand the effect of store image on consumer evaluation of PBs (e.g. Beneke \& Carter, 2015; Beneke \& Zimmerman, 2014; Beristain \& Zorrilla, 2011; Liljander et al., 2009; Semeijn, van Riel \& Ambrosini, 2004). In particular, these studies found that favourable store image helps fuel positive attitudes towards PBs, suggesting that the functional or psychological attributes of a store may be easily transferable to PBs which the store provides (Beneke \& Carter, 2015; Beristain \& Zorrilla, 2011; Collins-Dodd \& Lindley, 2003; Vahie \& Paswan, 2006; Wu et al., 2011). Beneke and Carter (2015) point out that consumers tend to rely more heavily on extrinsic cues, such as store image, to make rational assessment of PBs when they do not have enough information about the product or when they have low product knowledge (expertise). Furthermore, Richardson, Jain and Dick (1996) posit that if consumers find the store to be unattractive or poorly maintained, they tend to ascribe these traits to store's PB products, thus diminishing the overall impression of PBs. Semeijn et al. (2004) argue that store image improvements through service, merchan- 
dise and store layout can create favourable impressions of PBs by reducing the consumer's perceived risk associated with PB purchases. Thus, we propose that retailers with a more positive store image are more likely to form a more favourable PB image in the consumer's minds. Therefore, the following hypothesis is posed:

H1: Store image has a positive and direct effect on the private brand (PB) image.

\section{Service Quality and Private Brand (PB) Image}

Service quality is one of the most discussed and disputed concepts in the service quality and service marketing literature. Over the years, many scholars have sought to define and measure service quality using different theoretical lenses, known as the "Nordic approach" (Grönroos, 1984) and the "American approach" (Parasuraman, Zeithaml \& Berry, 1988) to service quality conceptualisation. The "Nordic approach" proposes that the customer's overall perception of service quality is composed of functional and technical quality, with technical quality (service outcome quality) being what the consumer gets after the service delivery process in buyer-seller interactions and functional quality (service process quality) referring to the interaction between the customer and employees during the service encounter (Grönroos, 1984). The "American approach" suggests that service quality is the function of the differences between expectation and performance along five service quality dimensions, namely reliability, responsiveness, assurance, empathy, and tangibles (Parasuraman et al., 1988).

Although Berry (1986) highlights that retail business is services business, it must be noted that the quality of service delivered by retailers is somewhat specific as retailers offer a mix of services and products (Siu \& Cheung, 2001). Consequently, the customer perception of service quality in a retail context is to some extent affected by the purchased product as well. The retail literature suggests that customers evaluate service quality at the overall level, attribute level, and at dimensional level (To, Tam, \& Cheung, 2013). At the overall level, Westbrook (1981) argues that the customer's evaluation of service quality is affected by two broad types of experiences, namely merchandiserelated experiences (i.e. the quality and availability of the goods and services) and instore experiences (i.e. interactions with store employees and the ease of walking around the store). At the attribute level, Baker, Grewal and Parasuraman (1994) suggest that store environment encompassing ambient attributes (e.g. music, scent, lighting), design attributes (e.g. physical facilities) or social attributes (e.g. customer responsiveness of store's personnel) play pivotal role in the customer's evaluation of service quality. In an attempt to bridge the Nordic and American schools of thought on service quality, Brady and Cronin (2001) proposed the hierarchical service quality model (HSQM) which was tested in a retail setting. According to Brady and Cronin (2001), service quality is a three-tiered concept, encompassing three primary dimensions: interaction quality, physical environment quality and outcome quality. Interaction quality refers to the perceptions of the customer concerning the interpersonal interactions which take place during service delivery. Three sub-dimensions of this primary dimension suggest that the employee's attitude, behaviour, and expertise are shaping the customer's perceptions of interaction quality. Physical environment quality refers to the quality of the surrounding environment or physical facilities, whereas outcome quality refers to consumers' evaluation of the purchase experience in the store (Brady \& Cronin, 2001). 
Prior research suggests that favourable assessment of retail service quality is associated with the positive behavioural outcomes, such as customer satisfaction and an intention to repurchase and recommend (Dabholkar et al., 1996; Siu \& Cheung, 2001). Studies by Swoboda et al. (2007), Wu et al. (2011), have highlighted the role of retail service quality in the consumer-decision making process in relation to PBs. Research conducted by Wu et al. (2011), in particular, found that direct association exists between retail service quality and PB image. Huang (2009) further explains that good retail service quality may lead to positive 'halo effect' towards the PBs offered by a retailer. In the light of the above, the following hypothesis is posed:

H2: Retail service quality has a positive and direct effect on the private brand (PB) image.

\section{MATERIAL AND METHODS}

The main goal of this study is to empirically validate a conceptual model in which: a) store image (conceptualised as a set of store's attributes) influences PB image, and b) service quality, conceptualised as a second order construct made-up of three dimensions: interaction quality, service environment quality, and outcome quality, influences PB image. Drawing on the conceptual model, the current study aims to offer answers to the following research questions:

RQ1: Does a 'halo effect' take place between the store image and the private brand image?

RQ2: How does the consumer's evaluation of the quality of service delivered by a retailer affect the image of its private brand?

In this study, we placed emphasis on two types of retail formats, namely hypermarkets and drugstores. Since most of past research on PBs focused on large supermarket and hypermarket grocery chains, previous findings cannot be easily generalised to other retail formats. To improve the validity of findings in the area of private branding, it becomes paramount that scholars conduct more research in the context of other retail formats (Calvo-Porral et al., 2013; Wu etal., 2011). Thus, in this study we selected a large hypermarket chain Konzum and a drugstore chain dm-Drogerie Markt, as target retailers which have established well-known multi-tiered PB programmes.

As suggested by Richardson et al. (1996), consumer propensity toward PBs varies among product categories. For the purpose of this study, two products were chosen: potato chips ( $K$ Plus brand), as a low-cost, low-risk and low-involvement product category, and a shower gel (Balea brand), a product category which carries higher purchase risk and a greater level of consumer involvement. The selection of product categories was based on the following criteria: (1) the products are bought regularly, and thereby, consumers are able to easily evaluate different aspects and perceptions related to their purchase; (2) they are product categories which have different levels of consumer involvement and degrees of risks associated with the purchase; and (3) they are product categories in which PBs have a significant market share. It should be noted that chosen PBs ( $K$ Plus and Balea) are brands owned by retailers who do not place the chain name prominently on their brand; thus, the relation between the PB name and the store brand name is less transparent to consumers.

Data were collected via a store intercept method in downtown Sarajevo, Bosnia and Herzegovina. Sarajevo is chosen as the prime location for this study due the following 
reasons: (1) it is the capital of Bosnia and Herzegovina and an important retail market; (2) both retailers ( $d m$-Drogerie Markt and Konzum) have more than ten stores in Sarajevo and thus consumers shop at and they are familiar with both retailer's stores; and ( 3 ) due to time and financial constraints, this location is deemed most suitable. A non-probability convenience sampling was employed to recruit respondents and collect the data. The surveys were administrated by undergraduate marketing research students, who were well trained and instructed in the store intercept and interviewing techniques. Given the specific focus of this study, the exit intercept method was thought to be most desirable. Upon approaching the respondents, the interviewers identified themselves, explained the purpose of the survey, and provided respondents with the definition of PBs and examples of such brands. To minimise the potential bias due to non-probability sampling, interviews were conducted on both weekdays and weekends during morning and late afternoon/evening hours. At the end of field work, a total of 699 usable questionnaires were obtained across two product categories, 359 for $K$ plus potato chips and 340 for Balea shower gel. A detailed breakdown of the sample characteristics, in terms of gender, age, income, educational attainment, and the frequency of PB purchases is shown in Table 1.

Table 1. Demographic characteristics of the sample

\begin{tabular}{|l|r|l|r|}
\hline \multicolumn{1}{|c|}{ Variable } & \multicolumn{1}{|c|}{ Variable } & $\%$ \\
\hline Gender & & Education & \\
\hline Female & 71.4 & High school & 31.7 \\
\hline Male & 28.6 & College or vocational school & 19.0 \\
\hline Age & & Bachelor's degree & 38.9 \\
\hline Under 20 years & 10.2 & Master's degree or higher & 10.3 \\
\hline $21-25$ years & 22.3 & Product category & \\
\hline $26-30$ years & 17.3 & Potato chips - K Plus & 51.4 \\
\hline $31-35$ years & 15.7 & Shower gel - Balea & 48.6 \\
\hline $36-40$ years & 13.3 & Purchase frequency & 38.9 \\
\hline 40 + & 21.1 & Seldom & 24.2 \\
\hline Income & & Sometimes & 46.9 \\
\hline Under BAM 1,000 & 26.8 & Often & 28.9 \\
\hline BAM 1,001-1,500 & 39.9 & & \\
\hline BAM 1,5001-2,000 & 26.6 & & \\
BAM 2,000 + & 6.7 & & \\
\hline
\end{tabular}

Source: own study.

The sample was slightly skewed towards females, approximately $2.5: 1$. This unequal gender distribution of the sample is in line with the assumption that women are usually more responsible for doing the shopping for the household than their male counterparts (Beneke, 2013). With regard to the frequency of PB purchases, more than three quarters (75.8\%) of respondents said they purchased PB either often or sometimes. This indicates that the sample consisted of consumers who are au fait with PBs.

The research instrument - the questionnaire compromised scales measuring the constructs of store image, service quality and PB image. The store image scale assessed consumers' perceptions of the store image based on the six store attributes: product variety, employee service, store atmosphere, prices, product quality and overall attitude. This scale was adopted from the works of Collins-Dodd and Lindley (2003) and Wu et al. 
(2011). For measuring service quality, we adopted the service quality instrument developed by Brady and Cronin (2001). Therefore, in this study service quality is viewed as a multidimensional construct encompassing three factors - interaction quality, service environment quality, and outcome quality. Following Keller's (1993) two-dimensional conceptualisation of brand image, we measured cognitive (quality) and affective (affection) dimensions of PB image. Specifically, PB image was assessed using a five-item scale developed by Vahie and Paswan (2006). All involved constructs were measured using seven-point Likert scale, ranging from 1 "strongly disagree" to 7 "strongly agree".

\section{RESULTS AND DISCUSSION}

The data analysis proceeded in three phases. First, the internal reliability of responses in multi-item scales was assessed by determining Cronbach's alpha coefficient and item-total correlations (Hair et al., 2010). The results revealed that the scales measuring store image (SI), interaction quality (IQ), outcome quality (OQ) and quality aspect of PB image (Q) are reliable with the present data (Table 2.). Also, the analysis found Cronbach's alpha to be less than the recommended value of 0.7 for two constructs: service environment quality (SEQ) and affective component of PB image (A). However, it should be noted that Cronbach's alpha value greater than 0.6 , with item-to-total correlations greater than 0.3 , is adequate for conducting research in social sciences (Hair et al., 2010). Second, the structural equation modelling (SEM) technique to examine the hypotheses in the proposed model was applied. Following Anderson \& Gerbing (1988) methodological suggestions, the two-step approach for assessing structural equation models was employed. The first stage involves the assessment of the measurement model and the second stage advances to testing the structural relationships (hypotheses) among the latent constructs. This approach avoids interaction between the measurement and structural models and re-specification errors (Hair et al., 2010).

To assess the reliability, convergent validity, and discriminant validity of constructs in the proposed model, confirmatory factor analysis (CFA) was employed. The measurement model was estimated using the maximum-likelihood method (MLM) and the model fit was tested using several fit indices. Hu and Bentler (1999) acknowledged that it is very difficult to specify a cut-off value for each fit index because it does not work equally well under various conditions. However, to enhance the interpretation of the findings, the following "benchmark" is being provided. Values for the Root Mean Square Error of Approximation (RMSEA) can range from zero to 1.0, whereas an RMSEA value of less than 0.5 indicates good fit, in the range of 0.05 to 0.10 is considered an indication of a fair fit, and values above 0.1 indicated poor fit (Maccallum, Browne \&Sugawara,1996). For the Standardized Root Mean Squared Residual (SRMR), the conventional cut-off point is less than 0.08 for a good-fitting model (Hu and Bentler, 1999). A normed chi-square value $\left(\chi^{2} / d f\right)$ of less than 5.0 has been suggested to indicate an adequate model fit (Scumacker \& Lomax, 2004). According to Hair et al. (2010), the Comparative Fit Index (CFI) and the Tucker-Lewis index (TLI) should be greater than 0.9. Traditionally, values of 0.9 and greater for Goodness-of-Fit Index (GFI) and the Adjusted Goodness of Fit Index (AGFI) indicate well-fitting models (Hooper, Coughlan \& Mullen, 2008). According to the model evaluation criteria suggested in the prior discussion, the 
overall fit of the measurement model to data was acceptable: $\chi^{2}=504.126(p<0.001)$; $\chi^{2} / \mathrm{df}=4.541 ; \mathrm{RMSEA}=0.071, \mathrm{SRMR}=0.061 ; \mathrm{CFI}=0.952 ; \mathrm{TLI}=0.941$.

Table 2. Scaling and measurement properties

\begin{tabular}{|c|c|c|c|c|}
\hline Constructs & Code & Dimensions and manifest variables & $\lambda$ & St. error \\
\hline \multirow{6}{*}{$\begin{array}{l}\text { Store image } \\
\text { (SI) } \\
\alpha=0.894\end{array}$} & si1 & This store provides a variety of products. & 0.535 & \\
\hline & si2 & The entire product in this store has good quality. & 0.855 & 0.173 \\
\hline & si3 & The entire product in this store has good low price. & 0.840 & 0.150 \\
\hline & si4 & The products of this store are good value for money. & 0.902 & 0.163 \\
\hline & si5 & $\begin{array}{l}\text { The interior decoration of this store let me feel pleas- } \\
\text { ant atmosphere. }\end{array}$ & 0.908 & 0.161 \\
\hline & si6 & Overall, I have positive attitude in this store. & 0.513 & 0.093 \\
\hline \multirow{2}{*}{$\begin{array}{l}\text { Interaction quality } \\
\text { (IQ) } \\
\alpha=0.902\end{array}$} & iq1 & $\begin{array}{l}\text { Overall, I'd say the quality of my interaction with this } \\
\text { store's employee is excellent. }\end{array}$ & 0.857 & \\
\hline & iq2 & $\begin{array}{l}\text { I would say that the quality of my interaction with this } \\
\text { store's employee is high. }\end{array}$ & 0.960 & 0.034 \\
\hline \multirow{2}{*}{$\begin{array}{l}\text { Service environment } \\
\text { quality (SEQ) } \\
\alpha=0.607\end{array}$} & seq1 & $\begin{array}{l}\text { I would say that store's physical environment is one of } \\
\text { the best in its industry }\end{array}$ & 0.583 & \\
\hline & seq2 & I would rate this store's physical environment highly. & 0.752 & 0.086 \\
\hline Outcome quality (OQ) & oq1 & I always have an excellent experience when I visit this store. & 0.937 & \\
\hline$\alpha=0.899$ & oq2 & I feel good about what this store provides to its customers. & 0.872 & 0.027 \\
\hline \multirow{3}{*}{$\begin{array}{l}\text { Quality private } \\
\text { brand mage } \\
\text { (Q) } \\
\alpha=0.817\end{array}$} & q1 & $\begin{array}{l}\text { Too many of the private label brand I buy at this store } \\
\text { are defective in some waya. }\end{array}$ & 0.910 & \\
\hline & q2 & $\begin{array}{l}\text { Most private label brand I buy at this store wear out } \\
\text { too quicklya. }\end{array}$ & 0.953 & 0.026 \\
\hline & q3 & $\begin{array}{l}\text { This store does not care enough about the quality of } \\
\text { its private label brand }{ }^{a} \text {. }\end{array}$ & 0.501 & 0.036 \\
\hline \multirow{2}{*}{$\begin{array}{l}\text { Affective private } \\
\text { brand image (A) } \\
\alpha=0.627\end{array}$} & a1 & I like the private label brand of this store very much & 0.614 & \\
\hline & a2 & $\begin{array}{l}\text { I am satisfied with most of the private label brand } \\
\text { I buy at this store. }\end{array}$ & 0.747 & 0.074 \\
\hline \multirow{3}{*}{ Service quality (SQ) } & $\mathrm{IQ}$ & Interaction quality & 0.934 & \\
\hline & SEQ & Service environment quality & 0.859 & 0.049 \\
\hline & $\mathrm{OQ}$ & Output quality & 0.981 & 0.049 \\
\hline \multirow{2}{*}{$\begin{array}{l}\text { Private brand image } \\
\text { (PBI) }\end{array}$} & Q & Quality PB image & 0.942 & \\
\hline & A & Affective PB image & 0.951 & 0.035 \\
\hline
\end{tabular}

Note: Goodness of fit: $\chi^{2}=504.126(p<0.001) ; \chi^{2} / d f=4.54 ;$ RMSEA $=0.071$, SRMR $=0.0605 ; C F I=0.952$;

$\mathrm{TLI}=0.941 .{ }^{\mathrm{a}}$ Reverse-coded items

Source: own study.

We then assessed the construct's internal consistency and validity. All constructs were deemed to be highly consistent and reliable, as their composite reliability (CR) scores were above the recommended cut-off value of 0.7 (Bagozzi \& Yi, 2012). According to Hair et al. (2010), convergent validity is satisfied if the standardised factor loading exceeds 0.5 , is significant at 0.001 , and average variance extracted (AVE) is greater than 0.5. As shown in Table 2, the standardised factor loading of items (manifest variables) and first-order constructs ranged from 0.501 to 0.981 , and all were statistically significant $(p<0.001)$. Average variance extracted of the three latent constructs $(\mathrm{SI}, \mathrm{SQ}$ and $\mathrm{PBI})$ ranged from 0.604 to 0.896 . These findings suggest that convergent validity is satisfied. Discriminant validity was assessed by comparing the square root AVE of each construct to its correlations with other constructs (Fornell \& Larcker, 1981). 
The results showed that discriminant validity of constructs is supported as the square root AVE of each construct is greater than the correlations between that construct and any other construct in the model. Table 3 displays $C R, A V E$, square root AVE and correlation values, supporting reliability, convergent and discriminant validity of constructs. Once the measurement model was validated, subsequent structural equation modelling (SEM) analyses were conducted to support the proposed model and to test the hypotheses. The results of the structural model (measurement and structural regression model) are shown in Figure 1.

Table 3. Reliability, convergent and discriminant validity of constructs

\begin{tabular}{|l|l|l|l|l|l|}
\cline { 2 - 7 } \multicolumn{1}{c|}{} & \multicolumn{4}{l|}{ Composite reliability and convergent validity } & \multicolumn{4}{l|}{ Discriminant validity } \\
\hline Construct & CR & AVE & SI & SQ & PBI \\
\hline Store image (SI) & 0.897 & 0.604 & $\mathbf{0 . 7 7 7}^{\text {a }}$ & & \\
\hline Service quality (SQ) & 0.947 & 0.858 & 0.192 & $\mathbf{0 . 9 2 6}$ & \\
\hline Private brand image (PBI) & 0.945 & 0.896 & 0.619 & 0.224 & $\mathbf{0 . 9 4 7}$ \\
\hline
\end{tabular}

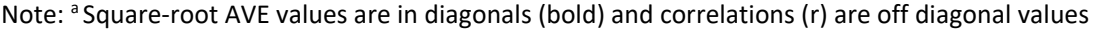
Source: own study.

The fitting indices of the structural model are as follows: $\chi^{2}=504.126(p<0.001) ; \chi^{2} / \mathrm{df}$ $=4.541 ; \mathrm{RMSEA}=0.071, \mathrm{SRMR}=0.061 ; \mathrm{CFI}=0.952 ; \mathrm{TLI}=0.941$. In comparison with the values suggested in the prior discussion, the findings demonstrate that the model's fit is satisfactory. Thus, it was deemed appropriate to test the hypothesised paths. As predicted by hypothesis $\mathrm{H} 1$, positive relationship between store image (SI) and private brand image $(\mathrm{PBI})$ was supported $(\beta=0.598 ; \mathrm{p}<0.001)$. Service quality (SQ) was also found to have a statistically significant positive influence $(\beta=0.109 ; p<0.001)$ on private brand image (PBI) providing the support for hypothesis $\mathrm{H} 2$. The predicted relationships, standardised, unstandardised coefficients, and hypotheses test outcomes are provided in Table 4. We also examined the predictive power of the structural model. According to Cohen (1988), the value of $R^{2}$ for endogenous latent variable $(0.26,0.13$, and 0.03$)$ can be used as the threshold to demonstrate substantial, moderate, and weak explanatory power of the model. In the present study, the findings suggest that $39.5 \%$ of the variance of private brand image (PBI) can be explained by store image (SI) and service quality (SQ), suggesting that the model provides substantial explanatory power.

The main finding of this study is that store image plays an important role in the imagebuilding of $\mathrm{PB}$, suggesting that consumers may derive inferences about $\mathrm{PB}$ image from their original perceptions of the retailer's store image. These results provide support for the accessibility-diagnosticity theory (Feldman \& Lynch, 1988) which assumes that consumers are "cognitive misers", in that they will not retrieve all possible information to make judgments (Meyvis \& Janiszewski, 2004). Instead, they will first try to retrieve the most accessible information. Because memory is related across nodes and structured into categories (e.g. store and private brand), consumers may draw inferences from one category to evaluate a related category. This is likely to occur if the information regarding the first category is highly accessible and more diagnostic than the other information from which a consumer derives judgments about the second (target) category. Whereas previous studies have demonstrated a positive effect of PB image on store image (e.g. Anselmsson, Johansson \& Persson, 2007; Kremer \& Viot, 2012), we empirically validated an effect of the opposite type - the image transfer from the store brand up to private brand. Thus, the more positively 


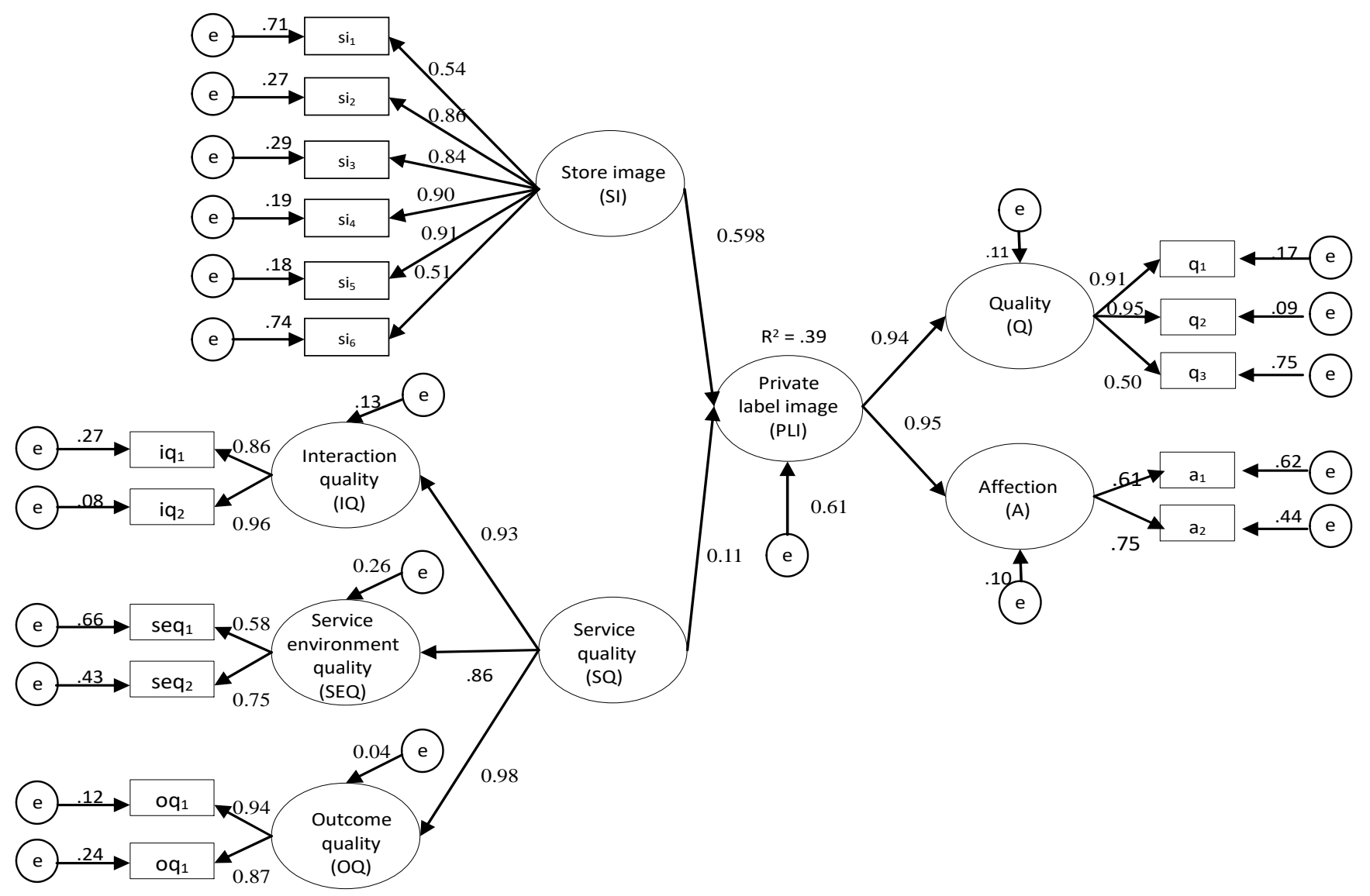

Figure 1. Structural model: Antecedents of PB image

Source: own elaboration. 
customers view a retailer's store, the more positively they will judge its private brands. The positive link between store image and $\mathrm{PB}$ image implies that the unique positioning of stores influences consumer's attitudes towards PB, as suggested by previous studies (e.g. Collins-Dodd \& Lindley, 2003; Semeijn et al., 2004; Wu et al., 2011).

Our findings also suggest that a perception of the quality of service offered by retailers has a positive effect on PB image. This result is in line with Wu et al. (2011) who found that in the Taiwanese market service quality directly affects PB image and has indirect effect on purchase intentions of PBs. Furthermore, the present study supports findings reported by Huang (2009), who found that the delivery of high service quality of retailers increases the perceived quality of their private brands. More specifically, among five retail service quality dimensions, Huang (2009) found that reliability and personal interactions have the strongest effects on the perceived quality of PBs. From a broader perspective, service marketing literature and retail literature also support the link between the quality of service delivered by a retailer and perceptions of PBs (e.g. Brady \& Cronin, 2001; Dabholkar et al., 1996; Swoboda et al., 2007).

\section{CONCLUSIONS}

Recent industry reports indicate that brands owned and sold by retailers (PBs) continue to chip away at the dominance of national (manufacturer) brands in terms of consumer's patronage, sales, and market share. Although researchers have investigated the antecedents of the consequences of PB image for more than a decade, more research is needed to clarify the role of intangible factors in the PB image building. Unlike most studies on PB image, this study is carried out in a transitional economy of South- Eastern Europe (i.e. Bosnia and Herzegovina) where the PB market penetration rate is significantly lower compared to the mature European and U.S. markets (Renko, 2013). Therefore, this study enhances the external validity (generalisability) of previous empirical findings beyond the Western context. At a broad level, our findings suggest that store image and the perception of service quality have a significant influence on PB image (both quality and affective dimensions), with store image having a slightly stronger influence. In other words, consumer's perception of the store attributes and the quality of service delivered by a retailer partially determine the success of a PB strategy.

This study offers some important insights for retailers who intend to develop their PB. First, the image transfer from store brand to private brand suggests that retailers should consider the introduction of a PB as a brand extension, with their stores as the parent brand. Specifically, retailers should try to integrate the image of the store (e.g. the quality and variety of product, store atmosphere, etc.) into the set of associations which make up the image of the PB. For instance, if the objective is to evoke an image of high quality or premium $\mathrm{PB}$, then the store attributes need to be modified accordingly. However, it should be noted that this 'halo effect' can also be harmful to PB image if store image is not properly managed. Therefore, retailers need to conjure up a strong and favourable store image in the minds of consumers, which will consequently enhance the image of their PBs. Recognizing the importance of store-related attributes in the image-branding of PBs, store managers should strive to elicit favourable store image by increasing product variety, enhancing product quality, offering the products in the price worthy of value, and pleasantly decorating the store. Given that service quality is one of the key drivers of PB image, we recommend that retailers put more emphasis on quality im- 
provement initiatives. Particularly, in order to form favourable and strong image of a PB, it is necessary to improve service environment quality, interaction quality and outcome quality. The store environment quality may be enhanced by remodelling the layout to make customers move easily around the store and to find PBs conveniently. Also, retailers may boost the quality of the store environment through careful selection of certain ambient elements, such as flooring, colouring, lightning, scent, etc. Interaction quality can be enhanced through the placement of knowledgeable, kind employees within the store. Because poor employee service, such as an employee's rude, hostile attitude and dishonest behaviour will lower the perceptions of service quality and, thus, lead to a decline in consumer's impressions about PB image, personnel training, and incentive salary may be a desirable method to promote and enhance employee's commitment to service quality. Finally, retailers should maintain the competitive price of their brands and improve the efficiency of customer service (pre-, during, and after-sale).

This study has several limitations. Firstly, this study focused only on two retail formats (hypermarkets and drugstores), two retail chains (Konzum and $d m$-Drogerie Markt), and two product categories (potato chips and a shower gel). Secondly, the data were collected exclusively in the retailer's stores located in the city of Sarajevo. Therefore, results may differ with respect to other domestic, regional and national markets, retail formats, retail chains and product categories. Future studies are therefore welcomed in expanding the domain of this research with respect to the geographical coverage, retail format, and product category. Furthermore, Stern, Zinkhan and Jaju (2001) found that marketing literature provides at least three different approaches to the store image conceptualisation and its measurement, namely functional, psychological, and complex gestalt. In this study we adapted the functional approach and, thereby, our measurement of store image is less powerful in capturing intangibles and psychological attributes (e.g. the attractiveness of the décor and style of the store; atmospheric cues, such as music, scent, colouring; friendliness or the congruence between store image and actual self-image), which are also considered to be key components of store image. Thus, future studies need to take into account tangible (functional) and intangible (psychological) components of store image and examine the extent to which they have different effects on the PB image. Moreover, further research should look at store image from a broader perspective and examine how retailer (corporate) image affects PB image. Finally, our study only examined the antecedents of PB image (i.e. store image and service quality), thus, future studies might also include behavioural outcomes, such as PB purchase or loyalty towards PBs.

\section{REFERENCES}

Aaker, D.A. (1991). Managing Brand Equity: Capitalizing on the Value of a Brand Name, Free Press, NY.

Ailawadi, K.L., \& Keller, K.L. (2004). Understanding retail branding: Conceptual insights and research priorities. Journal of Retailing, 80(4), 331-342.

Anderson, J., \& Gerbing, D. (1988). Structural equation nodeling in practice: A review and recommended two-StepaApproach. Psychological Bulletin, 103(3), 411-423.

Anselmsson, J., Johansson, U., \& Persson, N. (2007). Understanding price premium for grocery products: a conceptual model of customer-based brand equity. Journal of Product \& Brand Management, 16(6), 401-414.

Bagozzi, R.P., \& Yi, Y. (2012). Specification, evaluation, and interpretation of structural equation models. Journal of the Academy of Marketing Science, 40(1), 8-34.

Baker, J., Grewal, D., \& Parasuraman, A. (1994). The influence of Store Environment on Quality Inferences and Store Image. Journal of the Academy of Marketing Science, 22(4), 328-339. 
Bao, Y., Bao, Y., \& Sheng, S. (2011). Motivating purchase of private brands: Effects of store image, product signatureness, and quality variation. Journal of Business Research, 64(2), 220-226.

Beneke, J. (2013). The influence of perceived product quality, relative price and risk on customer value and willingness to buy: a study of private label merchandise. Journal of Product \& Brand Management, 22(3), 218-228.

Beneke, J., \& Carter, S. (2015). The development of a consumer value proposition of private label brands and the application thereof in a South African retail context. Journal of Retailing and Consumer Services, 25, 22-35.

Beneke, J., Brito, A., \& Garvey, K.A. (2015). Propensity to buy private label merchandise: the contributory effects of store image, price, risk, quality and value in the cognitive stream. International Journal of Retail \& Distribution Management , 43 (1), 43-62.

Beristain, J.J., \& Zorrilla, P. (2011). The relationship between store image and store brand equity: A conceptual framework and evidence from hypermarkets. Journal of Retailing and Consumer Services, 18(6), 562-574.

Berry, L.L. (1986). Retail Businesses Are Services Businesses. Journal of Retailing, 62(1), 3-6.

Bloemer, J., de Ruyter, K. (1998). On the relationship between store image, store satisfaction. European Journal of Marketing, 32(5/6), 499-513.

Brady, M.K., \& Cronin, J.J. (2001). Perceived Service Conceptualizing Approach Quality: A Hierarchical. Journal of Marketing, 65(3), 34-49.

Calvo-Porral, C., Martinez-Fernández, V.-A., Juanatey-Boga, O., \& Lévy-Mangín, J.-P. (2013). What matters to store brand equity? An approach to Spanish large retailing in a downturn context. Investigaciones Europeas de Dirección Y Economía de La Empresa, 19(3), 136-146.

Chowdhury, J., Reardon, J., \& Srivastava, R. (1998). Alternative Modes of Measuring Store Image: An Empiricial Assessment of Structured versus Unstructured Measures. Journal of Marketing Theory and Practice, 6(2), 72-86.

Collins-Dodd, C., \& Lindley, T. (2003). Store brands and retail differentiation: The influence of store image and store brand attitude on store own brand perceptions. Journal of Retailing and Consumer Services, 10(6), 345-352.

Cuneo, A., Lopez, P., \& Yague, M. (2012). Private label brands: measuring equity across consumer segments. Journal of Product \& Brand Management, 21(6), 428-438.

Dabholkar, P.A. (2000). A comprehensive framework for service quality: an investigation of critical conceptual and measurement issues through a longitudinal study. Journal of Retailing, 76(2), 139-173.

Dabholkar, P.A., Thorpe, D.I., \& Rentz, J.O. (1996). A Measure of Service Quality for Retail Stores: Scale Development and Validation. Journal of the Academy of Marketing Science, 24, 3-16.

Diallo, M.F. (2012). Effects of store image and store brand price-image on store brand purchase intention: Application to an emerging market. Journal of Retailing and Consumer Services, 19(3), 360-367.

Dobni, D., \& Zinkhan, G.M. (1990). In Search of Brand Image: A Foundation Analysis. Advances in Consumer Research, 17, 110-119.

Feldman, J.M., \& Lynch, J.G. (1988). Self-generated validity and other effects of measurement on belief, attitude, intention, and behavior. Journal of Applied Psychology, 73(3), 421-435.

Fornell, C., \& Larcker, D.F. (1981). Structural Equation Models with Unobservable Variables and Measurement Error: Algebra and Statistics. Journal of Marketing Research, 18(3), 382-388.

Grönroos, C. (1984). A Service Quality Model and its Marketing Implications. European Journal of Marketing. 18(4), 36-44.

Hartman, K.B., \& Spiro, R.L. (2005). Recapturing store image in customer-based store equity: A construct conceptualization. Journal of Business Research, 58(8), 1112-1120.

Hooper, D., Coughlan, J., \& Mullen, M. (2008). Structural equation modeling: guidelines for determining model fit. Electronic Journal of Business Research Methods, 6(1), 53-60.

$\mathrm{Hu}$, L., \& Bentler, P.M. (1999). Cutoff criteria for fit indexes in covariance structure analysis: Conventional criteria versus new alternatives. Structural Equation Modeling: A Multidisciplinary Journal, 6(1), 1-55.

Huang, M.-H. (2009). Using service quality to enhance the perceived quality of store brands. Total Quality Management \& Business Excellence, 20(2), 241-252. 
Huang, Y., \& Huddleston, P. (2009). Retailer premium own-brands: creating customer loyalty through own-brand products advantage. International Journal of Retail \& Distribution Management, 37(11), 975-992.

Johnson, J.L., Martin, K.D., \& Saini, A. (2012). The role of a firm's strategic orientation dimensions in determining market orientation. Industrial Marketing Management, 41(4), 715-724.

Keller, K.L. (1993). Conceptualizing, Measuring, and Managing Customer-Based Brand Equity. Journal of Marketing, 57(1), 1-22.

Kremer, F., \& Viot, C. (2012). How store brands build retailer brand image. International Journal of Retail \& Distribution Management, 40(7), 528-543.

Kumar, N., \& Steenkamp, J.E.M. (2007). Private Label Strategy: How to Meet the Store Brand Challenge. Havard Business School Press (Vol. 41). Harvard Business School Press.

Liljander, V., Polsa, P., \& van Riel, A. (2009). Modelling consumer responses to an apparel store brand: Store image as a risk reducer. Journal of Retailing and Consumer Services, 16(4), 281-290.

Maccallum, R.C., Browne, M.W., \& Sugawara, H.M. (1996). Power analysis and determination of sample size for covariance structure modeling of fit involving a particular measure of model. Psychological Methods, 13(2), 130-149.

Martineau, P. (1958). The Personality of the Retail Store. Harvard Business Review, 36(1), 47-55.

Martínez Salinas, E., \& Pina Pérez, J.M. (2009). Modeling the brand extensions' influence on brand image. Journal of Business Research, 62(1), 50-60.

Mazursky, D., \& Jacoby, J. (1986). Exploring the Development of Store Images. Journal of Retailing, 62(2), 145-165.

Mehrabian, A., \& Russell, J.A. (1974). An approach to environmental psychology. Cambridge Mass The MIT Press (Vol. 315).

Meyvis, T., \& Janiszewski, C. (2004). When Are Broader Brands Stronger Brands? An Accessibility Perspective on the Success of Brand Extensions. Journal of Consumer Research, 31(2), 346-357.

Olson, J.C., \& Jacoby, J. (1972). Cue utilisation in the quality perception process. In M. Venkatesan, Proceedings of the Third Annual Conference of the Association for Consumer Research (pp. 167-179). Chicago: Association for Consumer Research.

Parasuraman, A., Zeithaml, V.A., \& Berry, L.L. (1988). SERQUAL: A Multiple-Item scale for Measuring Consumer Perceptions of Service Quality. Journal of Retailing, 64(1), 12-40.

PLMA (2015). PLMA 2015 Private Label Yearbook, New York, NY: Private LabelManufacturers Association.

Richardson, P., Jain, A.K., \& Dick, A. (1996). The influence of store aesthetics on evaluation of private label brands. Journal of Product \& Brand Management, 5(1), 19-28.

Semeijn, J., van Riel, A.C.R., \& Ambrosini, A.B. (2004). Consumer evaluations of store brands: effects of store image and product attributes. Journal of Retailing and Consumer Services, 11(4), 247-258.

Siu, N.Y.M., \& Cheung, J.T.-H. (2001). A measure of retail service quality. Marketing Intelligence \& Planning, 19(2), 88-96.

Stern, B., Zinkhan, G.M., \& Jaju, A. (2001). Marketing Images: Construct Definition, Measurement Issues, and Theory Development. Marketing Theory, 1(2), 201-224.

Swoboda, B., Haelsig, F., Morschett, D., \& Schramm-Klein, H. (2007). An intersector analysis of the relevance of service in building a strong retail brand. Managing Service Quality, 17(4), 428-448.

Theodoridis, P.K., \& Chatzipanagiotou, K.C. (2009). Store image attributes and customer satisfaction across different customer profiles within the supermarket sector in Greece. European Journal of Marketing, 43(5/6), 708-734.

To, W.M., Tam, J.F.Y., \& Cheung, M.F.Y. (2013). Explore how Chinese consumers evaluate retail service quality and satisfaction. Service Business, 7(1), 121-142.

Vahie, A., \& Paswan, A. (2006). Private label brand image: its relationship with store image and national brand. International Journal of Retail \& Distribution Management, 34(1), 67-84.

Westbrook, R.A. (1981). Sources of Consumer Satisfaction with Retail Outlets. Journal of Retailing. 57(3), 68-85.

Wu, P.C.S., Yeh, G.Y.-Y., \& Hsiao, C.-R. (2011). The effect of store image and service quality on brand image and purchase intention for private label brands. Australasian Marketing Journal (AMJ), 19(1), 30-39. 
Yu, W., \& Ramanathan, R. (2012). Retail service quality, corporate image and behavioural intentions: the mediating effects of customer satisfaction. The International Review of Retail, Distribution and Consumer Research, 22(5), 485-505.

\section{Authors}

The contribution share of authors is equal and amounted to $1 / 3$ each of them.

\section{Adi Alić}

Assistant Professor at Marketing Department of the School of Economics and Business Sarajevo (SEBS), University of Sarajevo (Bosnia and Herzegovina). Research interests: retailing, branding, and international marketing.

Correspondence to: Adi Alić, PhD, School of Economics and Business Sarajevo, University of Sarajevo, Trg oslobođenja - Alija Izetbegović 1, 71000 Sarajevo, Bosnia and Herzegovina, email: adi.alic@efsa.unsa.ba

\section{Emir Agić}

Associate Professor at Marketing Department of the School of Economics and Business Sarajevo (SEBS), University of Sarajevo. Research interest: strategic marketing, marketing management, marketing analytics, and pricing.

Correspondence to: Emir Agić, PhD, School of Economics and Business Sarajevo, University of Sarajevo, Trg oslobođenja - Alija Izetbegović 1, 71000 Sarajevo, Bosnia and Herzegovina, email: emir.agic@efsa.unsa.ba

\section{Merima Činjarević}

Assistant Professor at Microeconomics Department of the School of Economics and Business Sarajevo (SEBS), University of Sarajevo. Research interest: applied microeconomics, consumer behaviour, and services marketing.

Correspondence to: Merima Činjarević, PhD, School of Economics and Business Sarajevo, University of Sarajevo, Trg oslobođenja - Alija Izetbegović 1, 71000 Sarajevo, Bosnia and Herzegovina, e-mail: merima.cinjarevic@efsa.unsa.ba

\section{Acknowledgements and Financial Disclosure}

The authors would like to thank the anonymous referees for their useful comments, which allowed to increase the value of this article.

\section{Copyright and License}

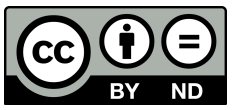

This article is published under the terms of the Creative Commons

Attribution - NoDerivs (CC BY- ND 4.0) License http://creativecommons.org/licenses/by-nd/4.0/

Published by the Centre for Strategic and International Entrepreneurship - Krakow, Poland 